Studies in African Linguistics

Volume 25, Number 2, Fall 1996

\title{
TONE-ACCENT AND PROSODIC DOMAINS IN WOLAITTA*
}

\author{
Azeb Amha \\ Leiden University
}

In Wolaitta, an Omotic language spoken in the south-central part of Ethiopia, simple phonological words are usually restricted to one high tone-accent per word. Nouns and adjectives have a similar tone-accent pattern, while verb roots differ from these in many respects. Morphology may alter the pattern in simple lexical forms in the sense that derivation and inflection may result in the presence of more than one high tone-accent in a word or, alternatively, in that they cause shift of the original tone accent. In nouns this depends on definiteness and the location of tone-accent in the citation form, while in verbs it is determined by the presence or absence of high tone-accent on the verb root and the type of suffix attached to it. High tone-accent marking in phrases can be predicted from the tone-accent pattern of the citation form of the modifier(s).

\section{Introduction}

The Wolaitta language, spoken by approximately 1.1 million people (OPHCC [1991:48]) in the south-central part of Ethiopia, belongs to the West Omotic language group. The term "Omotic" refers to a group of languages formerly known as the "Western Sidama group", classified as a sub-group of Cushitic. Since the 1960s, however, most scholars of Afro-Asiatic have accepted the classification of Omotic as separate from Cushitic. However, not all scholars agree on the internal sub-classification of these languages. Fleming [1976] sub-divides

* I am very grateful to Giorgio Banti, Frits Kortlandt, Harry van der Hulst, and Maarten Mous for their valuable comments and discussions on an earlier version of this paper. I am particularly indebted to Gerrit Dimmendaal for his insightful comments and for encouraging me to look into my language more closely. I would like to thank the Editor of SAL and an anonymous reader for their constructive comments and suggestions. I take full responsibility for any remaining shortcomings. Data on Wolaitta are based on the speech of the author, who speaks it as a first language. 
Omotic into two major subgroups, Western and Eastern, each with internal subdivisions, as illustrated in the tree diagram in (1).

(1) Omotic languages (based on Fleming [1976]) ${ }^{1}$

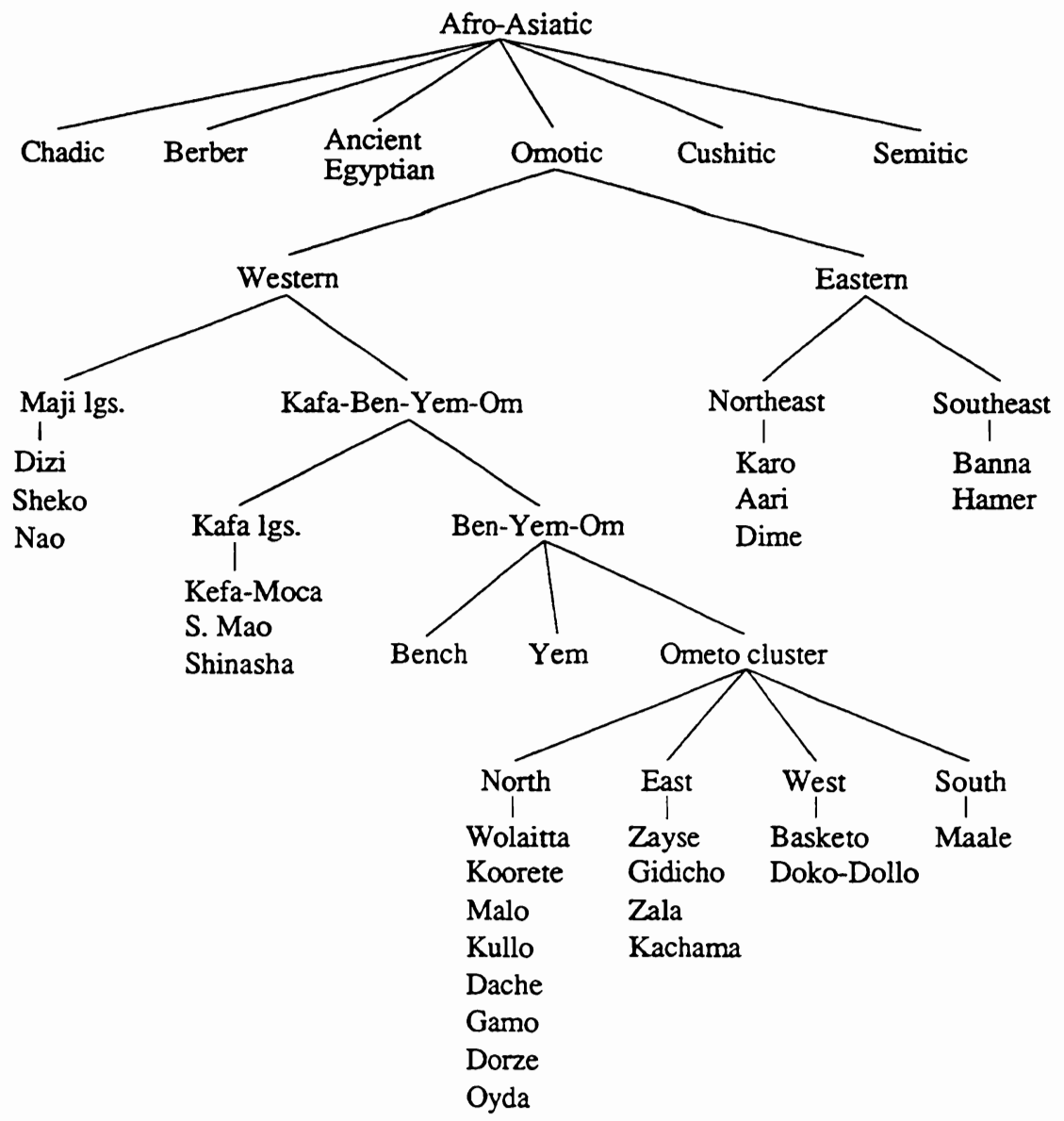

Since the Omotic language family consists of languages which have a variety of prosodic systems, it is important to investigate the situation in detail for each individual member. Recent studies on some of the Ometo languages have shown that, unlike in many other Omotic languages, the function of pitch in the Ometo group appears to be more in the grammatical and prosodic domain than in terms

${ }^{1}$ The names of some languages described in Fleming [1976] have been officially changed over the past few years. Thus, instead of Fleming's Gimojan, representing Gimira (now Bench), Ometo, and Janjero (now Yem), I have used Ben-Yem-Om, first suggested by Wedekind [1990]. 
of lexical distinctions. The chart in (2) shows the type of prosodic systems reported for Omotic languages (numbers next to the tone languages indicating the number of distinctive lexical tone types).

(2) Prosodic Systems Claimed for Some Omotic Languages 2

$\begin{array}{llll}\text { Tone } & \text { Tonal-accent } & \text { Accent } & \text { Tone \& Stress } \\ { } } & \text { Zayse } & \text { Aari } & \text { Koorete } \\ \text { Bench (6) } & \text { Gamo } & & \end{array}$

In previous studies Wolaitta has been described as a stress language (cf. Adams [1983] and Yitbarek [1983]). By considering Wolaitta to be a stress language, these studies did not account for the following two facts.

First, in accented long vowels the second mora receives tone-accent. This would not be possible in a stress language since the domain of stress is the syllable as a whole. Van der Hulst and Smith [1988:xi] take this to be a universal tendency of languages when they write: "... only the minimal syllable may be the bearer of stress... Hence we claim that the 'mora' is never the domain of stress."

Even though Adams [1983:54] states that "... sometimes a speaker will pronounce a long vowel with a slight pitch glide, which is also a characteristic of Wolaitta diphthongs", he analyses accented syllables with long vowels as having the same "stress" level. However, as in many mora counting tone-accent languages, Wolaitta exhibits a contour tone (i.e., a rising tone) in long accented syllables. These accented long syllables contrast with unaccented long syllables in which neither of the vowels bears high tone-accent. A similar situation is reported for Somali, in which contour tones occur only in long vowels (cf. Banti [1988]). Hyman [1981:169] considers this to be a defining characteristic of toneaccent languages: “... Somali is a tonal accent language, i.e., a language which (a) assigns accents to vowels (rather than syllables), and (b) realizes these accents as an invariant $\mathrm{H}$ tone."

Second, derived complex words have more than one high tone-accent. Adams makes reference to "higher pitch", "medium pitch", and "lower pitch" in his discussion of vocalic sequences, but he does not mention whether or not these correspond to various levels of stress, such as "primary" and "secondary" stress. In this paper, I claim that there is no such gradable distinction in prominence between two or more accented syllables in a word. In complex words consisting of more than one tone-accent, the accents are realized as high tone.

2 Information on Zayse, Aari and Gamo are from Hayward [1990a], [1990b], and [1994], respectively. Allan [1976] has also dealt with the Dizi tone system (among other topics of the grammar). Breeze [1988] presents a comparative study of the phonology of Dizi and Bench. The Bench tone system is also known through publications of Wedekind [1983 and 1985]. Ford [1990] has a section on Koorete phonology. 
Thus, Wolaitta does not belong to the category of stress languages. In the following discussion, I shall present an alternative analysis for this language.

In the first part of the paper the regular pattern of tone-accent assignment in the citation form of major lexical categories will be discussed. 3 The second section deals with the role of affixation, which allows the occurrence of more than one high tone-accent in a word. In the third part, it will be shown that the tone-accent marking of simple phrases is predictable from the high tone-accent placement in the citation form of the modifier. In expanded phrases, each modifier, except demonstratives and possessive pronouns, is assigned high toneaccent. Interestingly, high tone-accent is always marked on the modifier(s), but not on the head category in the phrase. Finally, syntactic categories that are never assigned tone-accent are discussed. In the present paper, high tone-accent is marked with ', non-high (low) is not marked.

\section{Major lexical categories}

As emphasized in many linguistic studies, the main characteristic of tone-accent languages is the presence of a distributionally restricted once per word or per phrase type of pitch change, e.g., rise or fall (cf. McCawley [1978], Childs [1989]). Wolaitta has a restricted high tone-accent marking in the citation form of various categories.

All lexical nouns and adjectives have only one high tone-accent. However, with some this high tone-accent occurs on the final vowel, while with others it occurs on the penultimate vowel. It is not possible to predict, either on the basis of word class or on the basis of meaning, whether the tone-accent will fall on the final or penultimate vowel of the noun or adjective.

In most Omotic languages, nouns and adjectives end in vowels which are often deleted when another morphological unit is added to the noun or adjective. (For a discussion on this see Hayward [1987]). In this paper, I will refer to such vowels in Wolaitta as 'citation-form final vowels'. Unlike in other Ometo languages such as Basketto, the citation-form final vowel in Wolaitta is not always deleted with affixation. As mentioned above, in some nouns and adjectives this final vowel receives the tone-accent.

Verbs, which always involve affixation, differ from nouns and adjectives in accentual behaviour, and are discussed separately in section 3 .

3 The term "citation form" is used in this paper to refer to the form of nouns and adjectives when they are unmarked for nominal inflection such as case, definiteness, or number. These are what are called "absolutive" forms in some published works of Omotic languages. Phonologically, citation form nouns and adjectives in Wolaitta are distinct from their inflected counterparts in having any one of $/-e /, \mid-o /$ or $/-a /$ vowel endings, which are sometimes deleted in affixation. For some nouns, however, the citation form and the form in the nominative or accusative case can be identical. For example, the citation form and the indefinite nominative form of nouns with the terminal vowel /e/ are identical. Nominals with the terminal vowel $/ a /$ and their indefinite accusative form are also formally the same. 
2.1. Simple nouns. With few exceptions, nouns in Wolaitta can be divided into two groups: (a) those that have tone-accent on the final mora (3), and (b) those that have tone-accent on the penultimate mora (4). For each group, examples of different word structures (=number of syllables and vowel length) are given. ${ }^{4}$

(3) High tone-accent on the final mora
a. zoré
'advice'
sawó
'divorced woman'
zaré 'lizard'
pengé 'door'
šempó
'soul'
morgé 'nape of neck'
tamá
'fire'
molé
'fish'
saló
'sky
?awá
dirbá
'sun'
galbá
'haste'
'skin/hide(n.)'
b. leehé
maahé
'pumpkin'
deemó
'eye brow'
c'ooc'é 'hearth'
Paayó
'mother'
maayó
'cloth'
meegó
'cold'
maadó
'help'
c'ïšśá
'flower
dee ̌śá 'goat'
šooró
'neighbour'
c'uuččá 'louse'
c. Pec'eré 'rat' šukkaaré 'sweet pota
miširá 'bride'
gelešsó 'monkey'
sukul?ó 'guinea-fowl'

(4) High tone-accent on the penultimate mora

\begin{tabular}{|c|c|c|c|}
\hline $\begin{array}{l}\text { a. záre } \\
\text { Páyfe } \\
\text { kúse } \\
\text { lágge } \\
\text { tóho }\end{array}$ & $\begin{array}{l}\text { 'relative' } \\
\text { 'eye' } \\
\text { 'hand' } \\
\text { 'friend' } \\
\text { 'feet' }\end{array}$ & $\begin{array}{l}\text { zókko } \\
\text { mánk'o } \\
\text { Pák'o } \\
\text { Pál?o } \\
\text { c'účča }\end{array}$ & $\begin{array}{l}\text { 'back' } \\
\text { 'poor' } \\
\text { 'property' } \\
\text { 'expensive' } \\
\text { 'saliva' }\end{array}$ \\
\hline $\begin{array}{l}\text { b. K'oóre } \\
\text { huúp'e } \\
\text { siíre } \\
\text { t'iille } \\
\text { k'aác'o }\end{array}$ & $\begin{array}{l}\text { 'neck' } \\
\text { 'hair' } \\
\text { 'nose', } \\
\text { 'flour' } \\
\text { 'ant' }\end{array}$ & $\begin{array}{l}\text { tuúmmo } \\
\text { t'aáro } \\
\text { boóra } \\
\text { buút'a } \\
\text { tuússa }\end{array}$ & $\begin{array}{l}\text { 'garlic' } \\
\text { 'pot' } \\
\text { 'ox' } \\
\text { 'dry grass' } \\
\text { 'central pillar }\end{array}$ \\
\hline
\end{tabular}

4 Phonetic symbols have the usual IPA values, except that $/ \check{s} /$ is used instead of IPA $/ 5 /$, for a 'voiceless alveopalatal fricative', $\Gamma c /$ is used instead of $h J /$ for a voiceless alveopalatal affricate, $|\bar{j}|$ is used instead of $/ d_{3} /$ for the voiced alveopalatal affricate. 

c. Pudúnt'e 'fly' zazzáre 'sieve'
birádde 'finger'
bullúkko 'garment'
namisa 'hunger'

$\begin{array}{ll}\text { mek'étta } & \text { 'bone' } \\ \text { bulláčča } & \text { 'wedding' } \\ \text { dangársa } & \text { 'elephant' } \\ \text { Pomársa } & \text { 'night' } \\ \text { Pint'ársa } & \text { 'tongue' }\end{array}$

d. Pallaálle

'business'

k'unc'uúte

'thread'

malaáta 'sign'

Pakeéka 'caution'

$\begin{array}{ll}\text { buddeéna } & \text { 'kind of pan cake' } \\ \text { hargaác'a } & \text { 'fatigue' } \\ \text { bit'aála } & \text { 'bridle' } \\ \text { goopíne } & \text { 'lung' }\end{array}$

e. dangirit'e 'retainer'

goromoóte 'evil eye'

šroroóte 'spider'

A few trisyllabic and quadrisyllabic words constitute exceptions to the final or penultimate mora tone-accent marking, having the high tone-accent on the antepenultimate mora, as illustrated in (5).

(5) High tone-accent on the ante-penultimate mora

$\begin{array}{llll}\text { másunta } & \text { 'wound' } & \text { k'ángetta } & \text { 'curse' } \\ \text { súk'k'unta } & \text { 'hot ashes, cinder' } & \text { Páfutta } & \text { 'tears' } \\ \text { sírk'unta } & \text { 'hiccup' } & \text { woláwušse } & \text { 'hepatitis' } \\ \text { k'éretta } & \text { 'split wood' } & \text { kórima } & \text { 'bull' }\end{array}$

Note the similarity of these words in terms of tone-accent assignment to higher numerals given in (6).
(6)

$\begin{array}{ll}\text { Pusúppuna } & \text { 'six' } \\ \text { laáppuna } & \text { 'seven' } \\ \text { hóspuna } & \text { 'eight' } \\ \text { Pudúpuna } & \text { 'nine' }\end{array}$

There are only a few words of this type in Wolaitta, each ending with /-nta/, /-tta/ or /-puna/. It seems likely that these are historically complex words consisting of more than one morpheme, and will not be discussed further here. 5

5 Fleming [1976:50] states that the form /-puna/ 'five' is an innovation shared by the Ometo, Bench, and Yem languages. Thus, we could say /Pusúppuna/ 'six' and /laáppuna/ 'seven' analysed as /Pissó/ 'one' plus /puna/ 'five' and /lam-/ 'two' plus /puna/ 'five', respectively, are compound or complex words, and tone-accent, like in other compound nouns in this language, is marked on the left most component of the compound. This, however, should be said with some reservation since the synchronic form for 'five' in Wolaitta is Piccáfa. Borrowing could also be 
2.2. Pronouns. Subject pronouns take a high tone-accent on the final mora, object pronouns a falling tone-accent.

(7)

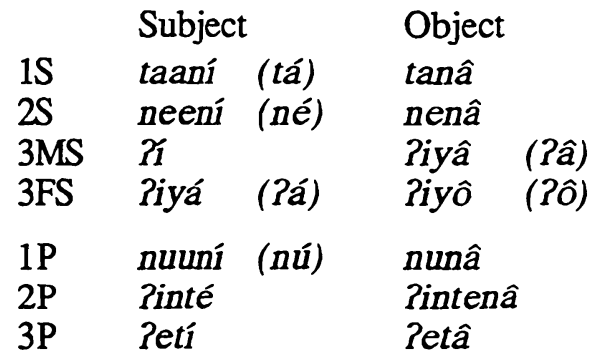

The forms in brackets are shorter variants of the full forms; they can be used interchangeably. The tone-accent assignment in object pronouns constitutes an analytical problem, since falling tone-accent on short vowels has not been observed in other categories in Wolaitta. This apparent irregularity will not be dealt with in this paper, but merits further investigation.

2.3. Adjectives. Adjectives, like nouns, have tone-accent on either the penultimate (8) or the final (9) mora. Adjectives having high tone-accent on the final mora are fewer in number.

\begin{tabular}{|c|c|c|c|}
\hline $\begin{array}{l}\text { (8) a. lóp?o } \\
\text { túna } \\
\text { t'úma } \\
\text { c'íma } \\
\text { dámma }\end{array}$ & $\begin{array}{l}\text { 'good' } \\
\text { 'blunt' } \\
\text { 'dark' } \\
\text { 'old' (of humans) } \\
\text { 'dumb' }\end{array}$ & $\begin{array}{l}\text { yelága } \\
\text { t'et't'éla } \\
\text { karétta } \\
\text { Pazálla }\end{array}$ & $\begin{array}{l}\text { 'young' } \\
\text { 'smart' } \\
\text { 'black' } \\
\text { 'lazy' }\end{array}$ \\
\hline $\begin{array}{l}\text { b. boóza } \\
\text { buúk’a } \\
\text { c'eéga } \\
\text { keéha } \\
\text { Piíta }\end{array}$ & $\begin{array}{l}\text { 'untidy, ineffective' } \\
\text { 'rotten' } \\
\text { 'old' (of objects, pets) } \\
\text { 'kind' } \\
\text { 'bad' }\end{array}$ & $\begin{array}{l}\text { çaála } \\
\text { laáfa } \\
\text { boótta } \\
\text { guútta }\end{array}$ & $\begin{array}{l}\text { 'sour' } \\
\text { 'little, skinny' } \\
\text { 'white' } \\
\text { 'small' }\end{array}$ \\
\hline $\begin{array}{c}\text { (9) a. c'amó } \\
\text { gitá } \\
\text { Parsá } \\
\text { woggá }\end{array}$ & $\begin{array}{l}\text { 'bitter' } \\
\text { 'big' } \\
\text { 'light colored' } \\
\text { 'big' }\end{array}$ & Padussá & 'tall' \\
\hline
\end{tabular}

considered to be the source of such words. At least the last word in (5), i.e., kórima, exists in other Ethiopian languages as well (compare Amharic/korma/ 'bull' and Oromo kórmaa 'male animal'). 

b. kaaló 'younger (of sibling)'
k'eerá 'small'
bayrá 'older (of sibling)'
duurá
'unruly'

Adjectives that have tone-accent on the antepenultimate mora have not been observed. In fact, the number of trisyllabic adjectives is relatively small, and, except for ideophonic adjectives (which often involve full or partial reduplication), no other quadrisyllabic adjectives have been recorded. Ideophonic adjectives have penultimate tone-accent (10).

$\begin{array}{ll}\text { (10) lošóš̃a } & \text { 'weak' } \\ \text { bo「fóf̆fa } & \text { 'light coloured' } \\ \text { wurk'uúk'a } & \text { 'dirty' } \\ \text { bunduruúk'a } & \text { 'messy' } \\ \text { K'azzázza } & \text { 'tall and handsome' }\end{array}$

The preceding sections can be summarized as follows. Vowel quantity and quality do not affect tone-accent assignment. All five vowels of the language can carry tone-accent: k'ita 'dirty', kúše 'hand', Péra 'knowledge', tóho 'feet', záre 'relative. These vowels have long counterparts which may or may not be assigned tone-accent, as illustrated by the examples in (11).
(11)

biittá 'country/soil'
suútta 'blood'
keéha 'kind'
c'ooc'é 'hearth'
šaára
šaará
'pregnant'
haattá
Pallaálle
'cloud'
'water'
'business'

When a word medial long vowel is accented, it is always the second mora that carries the tone-accent (for word final accented long vowels, see 3.1.1 below). Hence, Wolaitta must be considered as having a mora marking system. None of the consonants, including the glides $/ y /$ and $/ w /$, function as moraic units. Where $/ y /$ and $/ w /$ occur in diphthongs, it is the vowel that receives the tone-accent, as in (12). 6

$6 / y /$ and $/ w /$ exhibit different degrees of stricture in various positions in a word. Thus, in initial position in words like /yeéso/ 'fresh milk' and /waaso/ 'noise' they have more stricture; intervocalically and as first members of a consonant cluster, as in /haysé/ 'story' and / kawřšal 'scandalous' they occur with less stricture. The highest stricture for $/ y /$ can be heard when it is geminated word medially as in /Peéyya/ 'moron', / Paayyial 'the mother' (nom), and ?áyyo 'boasting'. (See also Adams [1983] who discusses this issue at length.) 

(12)

$\begin{array}{ll}\text { giyá } & \text { 'market' } \\ \text { Paayó 'mother' } \\ \text { kawá 'king' } \\ \text { Pawá 'sun' } \\ \text { báwta 'carcass, dead body' }\end{array}$
c’áyo
'insulting'
Páyyo 'boasting'
káwo 'dinner'
móysa 'to see sb. off, farewell'

Positionally, two contrasts have been observed. With very few exceptions, tone-accent is marked either on the final or the penultimate mora. The penultimate position has only high tone-accent, whereas the final position exhibits both a high and a falling tone-accent on short vowels; this falling tone-accent occurs only with object pronouns.

\section{Tone accent and affixation}

The importance of morphology in the analysis of prosodic systems has been well emphasised in the linguistic literature. Van der Hulst (in press) writes: “...affixes may have accentual properties of their own. Such affixes may be marked for receiving the primary accent, or they might determine the primary accent location in some way (by being pre- or post-accenting..." This has been attested in several languages. For example, Newman [1986] divides Hausa affixes into two types: "tone integrating affixes" and "non tone integrating affixes". The former affect (override) the lexical tone of the stem, while the latter do not affect the stem tone. Withgott and Halvorsen [1988:281] write for Norwegian: "Prefixes and suffixes are categorized according to which tone they assign and in terms of their dominance."

A similar situation can be observed in Wolaitta accent marking. Adams [1983:66] has pointed out that "[t]he predictability of Wolaitta stress is morphologically oriented." He shows that some morphemes, such as future marking morphemes and the plural morpheme, attract stress. He calls these "auto stressed". On the other hand, the vocative morpheme gets its preceding syllable stressed, which Adams labels "recessively" stressed. According to his analysis, the causative morpheme results in a shift of the stress in the original form (but see below). He also lists morphemes according to their accentual strength. In this section, I present further data on the forms dealt with by Adams. In addition, data on topics he overlooked are provided. Particularly relevant are verbal inflections and derivations which involve more than one high tone-accent. Furthermore, examples of nominal derivation and their effect on tone-accent pattern will be shown. All affixation in Wolaitta involves suffixes. 


\subsection{Noun Morphology}

3.1.1 Nominal Inflection. Definiteness interacts with case and gender marking in Wolaitta. ${ }^{7}$ Nominative case is marked for both definite and indefinite nouns, except those ending with $/-e /$, which are not inflected for indefinite nominative and only lengthen the citation form final vowel in the definite nominative. Definite and indefinite are not distinguished in plural nouns as they are in the singular. Inflection for case and number may shift the tone-accent of the base noun. This shift is shown in the paradigms in (13) and (14), where words are grouped into two categories depending on the location of the tone-accent.

(13) Inflection of nouns having high tone-accent on the penultimate mora (of the citation form)

\begin{tabular}{|c|c|c|c|c|c|c|}
\hline \multicolumn{2}{|c|}{ a. Citation form } & b. Indf. nom. & c. Def. nom. & d. Def. acc. & e. Pl. nom. & f. $\underline{\mathrm{Pl}}$ acc. \\
\hline záre & 'relative' & záre & záree & záriya & záreti & záreta \\
\hline kúšse & 'hand' & kúše & kúšee & kúšiya & kúšeti & kúšeta \\
\hline tire & 'liver' & tire & tíree & tiriya & tireti & tíreta \\
\hline tóho & 'feet' & tóhi & tóhoy & tóhuwa & tóhoti & tóhota \\
\hline mára & 'calf' & mári & máray & máraa & márati & márata \\
\hline dirsa & 'fence' & dirsi & dirsay & dirsaa & dirsati & dirsata \\
\hline $\begin{array}{l}\text { Pársa } \\
\text { boóra } \\
\text { mirzza }\end{array}$ & $\begin{array}{l}\text { 'bed' } \\
\text { 'ox' } \\
\text { 'cow' }\end{array}$ & $\begin{array}{l}\text { Pársi } \\
\text { boóni } \\
\text { miúzza }\end{array}$ & $\begin{array}{l}\text { Pársay } \\
\text { boóray } \\
\text { mirzziva }\end{array}$ & $\begin{array}{l}\text { Pársaa } \\
\text { boóra } \\
\text { miüzzivo }\end{array}$ & $\begin{array}{l}\text { Pársati } \\
\text { boórati }\end{array}$ & $\begin{array}{l}\text { Pársata } \\
\text { boórata } \\
\text { mürzata }\end{array}$ \\
\hline
\end{tabular}

(14) Inflection of nouns having high tone-accent on the final mora (of the citation form)

\begin{tabular}{|c|c|c|c|c|c|c|}
\hline \multicolumn{2}{|c|}{ a. Citation form } & b. Indf. nom. & c. Def. nom. & d. Def. acc. & e. Pl. nom. & f. $\underline{\mathrm{Pl}}$ acc. \\
\hline zaré & 'lizard' & zaré & zarée & zaríya & zaretí & zaretá \\
\hline haré & 'donkey' & haré & harée & hariya & hareti & haretá \\
\hline toorá & 'spear & toori & tooráy & tooráa & tooratí & tooratá \\
\hline fok'ó & 'peel' & fok'í & fok'óy & fok'úwa & fok'otí & fok'otá \\
\hline $\begin{array}{l}\text { Parsá } \\
\text { maldó } \\
\text { gelešsóó }\end{array}$ & $\begin{array}{l}\text { 'lgt colored' } \\
\text { 'sorghum' } \\
\text { 'monkey' }\end{array}$ & $\begin{array}{l}\text { Parsí } \\
\text { maldí } \\
\text { gelešši }\end{array}$ & $\begin{array}{l}\text { Parsáy } \\
\text { maldóy } \\
\text { geleššóy }\end{array}$ & $\begin{array}{l}\text { Parsáa } \\
\text { maldúwa } \\
\text { geleššúwa }\end{array}$ & $\begin{array}{l}\text { Parsatí } \\
\text { maldotí } \\
\text { geleššotí }\end{array}$ & $\begin{array}{l}\text { Parsatá } \\
\text { maldotá } \\
\text { geleššotá }\end{array}$ \\
\hline $\begin{array}{l}\text { gelešssó } \\
\text { miččó }\end{array}$ & 'sister' & miččá & miččiya & miččiyo & miččoti & miččotá \\
\hline Paayó & 'mother' & Paayá & Paayyía & Paayyío & Paayotí & Paayotá \\
\hline
\end{tabular}

7 The nominative case marker is /-i/ for masculine and /-a/ for feminine. The accusative case marker is $/-a /$ for masculine and $/-o /$ for feminine. When the accusative marker $/-a /$ is atrached to nouns ending in /-e/, a glide is formed, resulting in the ending /iya/. The indefinite accusative forms are identical to the citation form. 
The paradigms show that penultimate tone-accent in nouns (13) is not affected by the affixation of inflectional markers. On the other hand, citation form final toneaccent (14) shifts in the plural. Thus, we have in (13): /kúše/ 'hand' > /kúšeti/ 'hands', /záre/ 'relative' > /záreti/ 'relatives', but in (14) /zaré/ 'lizard' > /zaretil and /harél 'donkey' > /hareti/ 'donkeys'.

It was shown in the previous section that, in simple noun phrases, the second mora of an accented long vowel receives high tone-accent. Word final long vowels on the other hand receive high tone-accent on the first mora as in (14c) /zarée/ 'the lizard' and /harée/ 'the donkey'.

3.1.2. Nominal Derivation. Nominal derivation changes the tone-accent pattern of the base noun. The suffixes /-ta/, /-tétta/, /-amá/, /-ánčá/ derive 'abstract' or 'agentive' nominals; /-tétta/ derives nominals from adjectives, as well. Such derivational processes cause a shift of the high tone-accent of the original noun, and they also result in more than one accented mora in a noun. In (15b-d), the derived nominals have two accented syllables.

(15) a. - ta suffixes

$\begin{array}{llll}\text { laggéta } & \text { 'friendship' } & \text { < lágge 'friend' } \\ \text { siik'óta } & \text { 'love' } & <\text { siîk'o 'loved one' }\end{array}$

b. -tétta suffixes

$\begin{array}{llll}\text { kawótétta } & \text { 'kingdom' } & <\text { kawó 'king' } \\ \text { šoorótétta } & \text { 'neighbourhood' } & <\text { šooró 'neighbour' } \\ \text { durététta } & \text { 'richness' } & <\text { dúre } & \text { 'rich' } \\ \text { minótétta } & \text { 'strength' } & <\text { míno 'strong' } \\ \text { keehátétta } & \text { 'kindness' } & <\text { keéha } & \text { 'kind' }\end{array}$

c. -ámá suffixes

\begin{tabular}{|c|c|c|}
\hline $\begin{array}{l}\text { wolk'aámá } \\
\text { doonaámá } \\
\text { wozannaámá }\end{array}$ & $\begin{array}{l}\text { 'one with power' } \\
\text { 'talkative one' } \\
\text { 'smart one; one }\end{array}$ & $\begin{array}{l}\text { < wolká } \\
<\text { dooná } \\
<\text { wozaná }\end{array}$ \\
\hline
\end{tabular}

d. -ánčá suffixes

$\begin{array}{llll}\text { go ̌šánčá } & \text { 'farmer' } & <\text { gošsá 'farm' } \\ \text { hargánčá } & \text { 'patient' } & <\text { hargé 'illness' } \\ \text { wordánčá } & \text { 'liar' } & <\text { wordó 'a lie' } \\ \text { Podánčá } & \text { 'gossiper' } & \text { < Pódo 'news' }\end{array}$

The vocative suffix /-o/ places a tone-accent on the penultimate mora. Thus, nouns having a final tone-accent in citation form replace it with a penultimate 
tone-accent (16). Nouns accented on the penultimate mora in citation form, on the other hand, maintain the tone-accent on the penultimate in the vocative (17).

(16)

Vocative - $O$ forms

$\begin{array}{llll}\text { Pišo } & \text { 'Oh, brother!' } & <\text { Pišá } & \text { 'brother' } \\ \text { Paáyo } & \text { 'Oh, mother!' } & <\text { Paayó } & \text { 'mother' } \\ \text { Paáwo } & \text { 'Oh, father!' } & <\text { Paawá } & \text { 'father' } \\ & & & \\ \text { lággo } & \text { 'Oh, friend!' } & <\text { lágge } & \text { 'friend' } \\ \text { gódo } & \text { 'Oh, lord/chief!' } & <\text { góda } & \text { 'lord/ chief' }\end{array}$

A similar situation exists in Somali. According to Banti [1988:24], "Vocatives in Somali uniformly have high tone on their first mora and low on their other moras." Furthermore, as noted in Adams [1983], the plural form of vocative nouns such as those in (16) gets "stress" (tone-accent in our terms) on the final vowel of the suffix while those in (17) keep tone-accent in the same position.
(18)
Pišató
'Oh, brothers!'
'Oh, mothers!'

But note that those in (17) keep tone-accent in the same position in the plural (19).
(19)
lággeto 'Oh, friends!'
gódato 'Oh, lords/chiefs!'

The nominal inflection and derivation show that 'tone integrating affixes' affect only the high tone-accent on citation form final vowel.

3.2. Verb Morphology. Verb roots in Wolaitta have the following canonical forms: C-, CVC-, CVVC-, CVCC-, and, for a very small set, CVC(C)VC(C)-. Every lexical verb has at least one suffix, and ends in a vowel.

3.2.1. The Infinitival Verb. That some verb roots are accented while others are not accented can be seen in the infinitival form of the verb. The infinitival morpheme is /-etta/.

(20) a. Accented

$\begin{array}{llll}\text { káretta } & \text { 'to cut branches' } & \text { fitetta } & \text { 'to sweep' } \\ \text { kácetta } & \text { 'to tie' } & \text { k'ángetta } & \text { 'to curse' } \\ \text { K'éretta } & \text { 'to split wood' } & \text { mándetta } & \text { 'to bet' } \\ \text { zéretta } & \text { 'to saw' } & \text { mírk'etta } & \text { 'to turn, twist' }\end{array}$


(20) a. Accented (continued)

$\begin{array}{llll}\text { Kaác'etta } & \text { 'to scratch' } & \text { zigiretta 'to gossip' } \\ \text { laáletta } & \text { 'to scatter' } & \\ \text { heémetta } & \text { 'to herd' } & \\ \text { wuúk'etta } & \text { 'to steal' } & \end{array}$

b. Unaccented

$\begin{array}{llll}\text { beRettá } & \text { 'to see' } & \text { Kaarettá 'to uncover' } \\ \text { šoc'ettá } & \text { 'to hit' } & \text { laačettá } & \text { 'to lick' } \\ \text { bayzettá } & \text { 'to sell' } & \text { laafettá 'to lose weight' } \\ \text { singettá } & \text { 'to smell' } & \text { laamettá 'to change' } \\ \text { šammettá } & \text { 'to buy' } & \text { maadettá 'to help' } \\ \text { Pimmettá } & \text { 'to give' } & \text { doorettá } & \text { 'to choose' } \\ & & \text { kiitettá } & \text { 'to send' }\end{array}$

In (20a), the high tone-accent is marked on the first vowel of the verb root, while in (20b) it is marked on the final mora of the suffix. The different behaviour of accented and unaccented verb roots can be seen in the inflection of these forms for aspect and negation, which are discussed in the next section.

3.2.2. Verb Inflection. In this section, tone-accent as a corollary of the inflection of verbs for aspect, person, and number is discussed. The perfective and imperfective forms which have distinct forms for person, number, and gender of the subject are shown in (21) and (22). In Wolaitta, the verb is not inflected for object nouns. The data in (21a and b) represent the inflection of unaccented verb roots, those in (22a and b) inflection of accented verb roots. The paradigms show that in non-accented roots high tone-accent is marked on the suffix, which in this case occurs on the first vowel of the suffix. In the accented verb roots, on the other hand, high tone-accent is not marked on the suffix. In the perfective, first and third person singular forms have two variants, which can be used interchangeably, but, according to this author, /wuúk'k'-adisi/ 'I stole' and /šammadisi/ 'I bought' sound more "archaic" than /wuúk'k'-aasi/ and /šamm-aási/.

(21) Unaccented Roots

\begin{tabular}{|c|c|c|c|}
\hline Perfective & & Imperfective & \\
\hline $\begin{array}{l}\text { šamm-ádisi/šamm-aási } \\
\text { šamm-ádasa } \\
\text { šamm-ídesi/šamm-iísi } \\
\text { šamm-ádusu/šammaásu } \\
\text { šamm-ída } \\
\text { šamm-ídeta } \\
\text { šamm-ídosona }\end{array}$ & $\begin{array}{l}\text { 'I bought' } \\
\text { 'you bought' } \\
\text { 'he bought' } \\
\text { 'she bought' } \\
\text { 'we bought' } \\
\text { 'you (pl.) bought' } \\
\text { 'they bought' }\end{array}$ & $\begin{array}{l}\text { šamm-áysi } \\
\text { šamm-aása } \\
\text { šamm-eési } \\
\text { šamm-áwsu } \\
\text { šamm-oósi } \\
\text { šamm-eéta } \\
\text { šamm-oósona }\end{array}$ & $\begin{array}{l}\text { 'I buy' } \\
\text { 'you buy' } \\
\text { 'he buys', } \\
\text { 'she buys' } \\
\text { 'we buy' } \\
\text { 'you (pl.) buy' } \\
\text { 'they buy' }\end{array}$ \\
\hline
\end{tabular}


(22) Accented Roots
a.Perfective
wuúk'k'-adisi/wuúk'k'-aasi 'I stole' wuúk'k'-adasa 'you stole' wuúk'k'-adusu/wuúk'k'-aasúshe stole' wuúk'k'-idesi/wuúk'k'-iisi 'he stole wuúk'k'-ida wuúk'k'-ideta wuúk'k'-idosona
'we stole'
'you (pl.) stole'
'they stole'
b. Imperfective

wuúk'k'-aysi 'I steal'
wuúk'k'-aasa 'you steal'
wuúk'k'-awsu 'she steals'
wuúk'k'-eesi 'he steals'
wuúk'k'-oosi 'we steal'
wuúk'k'-eeta 'you (pl.) steal'
wuúk'k'-osona 'they steal'

Tone-accent marking in the future/intentional form, which is invariable for various subjects, and in the jussive and imperative moods, is presented in the paradigms in (23) and (24), which represent unaccented and accented verb roots, respectively. From the jussive inflection, only third person masculine singular and plural forms are chosen. In Wolaitta, as in most Omotic languages, the second person imperative form is not distinct for gender.

(23) Unaccented Roots

\begin{tabular}{|c|c|c|c|c|c|c|}
\hline \multirow{2}{*}{\multicolumn{2}{|c|}{ Infinitive }} & Future / & \multicolumn{2}{|c|}{ Imperative } & \multicolumn{2}{|c|}{ Jussive } \\
\hline & & Intentional & $\mathrm{Sg}$ & $\underline{\mathrm{Pl}}$. & $\underline{\mathrm{Sg}}$. & $\underline{\mathrm{Pl}}$. \\
\hline be?ettá & 'to see' & be?aná & be?á & be?ité & be?ó & be?óná \\
\hline šoc'ettá & 'to hit' & šoc'aná & šoc'á & šoc'ité & ร̌oc'ó & šoc'óná \\
\hline šamettá & 'to buy' & šammaná & šammá & šammité & jammó & šammóná \\
\hline Pimettá & 'to $q$ & Pimmaná & Pimmá & Pimmité & Pimmó & Pimmóná \\
\hline ettá & 'to & bayzzaná & bayzzá & bayzzité & bayzzó & bayz \\
\hline singettá & to & singaná & singá & singité & singó & singóná \\
\hline kiitettá & 'to send' & kiittaná & küittá & küttité & kiittó & kuittóná \\
\hline ettá & 'to choose' & dooraná & doorá & doorité & dooró & dooróná \\
\hline ettá & 'to change' & laammaná & laammá & laammité & laammó & laammóná \\
\hline ettá & weigh & laafaná & laafá & laafité & laafó & laafóná \\
\hline laac'ettá & 'to lick' & laac'c'aná & laac'c'á & laac'c'ité & laac'c'ó & laac'c'óná \\
\hline k'aarettá & 'to uncover' & k'aaraná & k'aará & k'aarité & k'aaró & k'aaróná \\
\hline $\begin{array}{l}\text { maadettá } \\
\text { laalukettá }\end{array}$ & $\begin{array}{l}\text { 'to help' } \\
\text { 'to roll («.)' }\end{array}$ & $\begin{array}{l}\text { maaddaná } \\
\text { laalukkaná }\end{array}$ & $\begin{array}{l}\text { maaddá } \\
\text { laalukká }\end{array}$ & $\begin{array}{l}\text { maaddité } \\
\text { laalukkité }\end{array}$ & $\begin{array}{l}\text { maaddó } \\
\text { laalukkó }\end{array}$ & $\begin{array}{l}\text { maaddóná } \\
\text { laalukkóná }\end{array}$ \\
\hline
\end{tabular}


(24) Accented Roots

\begin{tabular}{|c|c|c|c|c|c|c|}
\hline & \multirow{2}{*}{$\begin{array}{l}\text { Future | } \\
\text { Intentional }\end{array}$} & \multicolumn{2}{|c|}{ Imperative } & \multicolumn{2}{|c|}{ Jussive } \\
\hline & & & $\mathrm{Sg}$. & Pl. & $\mathrm{Sg}$ & Pl \\
\hline & 'to sv & fitta & fitta & fittite & fit & fitt \\
\hline & 'to split & $k^{\prime} e^{\prime}$ & & k'érite & 6 & óná \\
\hline & 'to saw & zér & & & & \\
\hline $\begin{array}{l}\text { k'aác'etta } \\
\text { mándetta }\end{array}$ & $\begin{array}{l}\text { 'to scratch' } \\
\text { 'to bet' }\end{array}$ & $\begin{array}{l}\text { k'aác'ana } \\
\text { mándana }\end{array}$ & $\begin{array}{l}\text { k'aác'a } \\
\text { mánda }\end{array}$ & $\begin{array}{l}\text { k'aác'ite } \\
\text { mándite }\end{array}$ & $\begin{array}{l}\text { k'aác'ó } \\
\text { mándó }\end{array}$ & $\begin{array}{l}\text { k'aác'óná } \\
\text { mándóná }\end{array}$ \\
\hline ángetta & 'to curse' & k’ángana & k’ánga & k’ángite & k'ángó & k'ángóná \\
\hline & 'to th & & bultele & mirkite & $k^{\prime \prime o ́}$ & nit \\
\hline $\begin{array}{l}\text { laáletta } \\
\text { heémetta }\end{array}$ & $\begin{array}{l}\text { 'to scatter' } \\
\text { 'to herd' }\end{array}$ & $\begin{array}{l}\text { laálana } \\
\text { heémmana }\end{array}$ & $\begin{array}{l}\text { laála } \\
\text { heémma }\end{array}$ & laálite & $\begin{array}{l}\text { laáló } \\
\text { heémmó }\end{array}$ & laálóná \\
\hline
\end{tabular}

The conjugation of four disyllabic verb roots-/zígir-/ 'to gossip', /hék' umm-/ 'to hiccup', / $k$ 'élt'umm-/ 'to vomit (of children)', and /saásuk-/ 'to whisper'-is shown in the paradigm below.

(25) Disyllabic verb roots

\begin{tabular}{|c|c|c|c|c|c|}
\hline & Future 1 & Impera & tive & Jussi & \\
\hline & Intentional & $\underline{S g}$. & $\underline{\mathrm{P}}$. & Sg. & Pl. \\
\hline & zígirana & zígira & zíginite & zígíró & zígíóna \\
\hline ietta & hék'ummana & hék'umma & hék'ummite & hék'úmmó & hék'úmmóná \\
\hline $\begin{array}{l}\text { netta } \\
\text { tta }\end{array}$ & $\begin{array}{l}\text { k'élt'ummana } \\
\text { saásukkana }\end{array}$ & $\begin{array}{l}\text { k'élt'umma } \\
\text { saásukka }\end{array}$ & $\begin{array}{l}\text { k'élt'ummite } \\
\text { saásukkite }\end{array}$ & $\begin{array}{l}\text { k'élt'úmmó } \\
\text { saásúkkó }\end{array}$ & $\begin{array}{l}\text { k'élt'úmmóná } \\
\text { saásúkkóná }\end{array}$ \\
\hline
\end{tabular}

Close examination of verb roots shows that most end in a closed syllable in Wolaitta. However, the verbs in (26) below are different in that they suggest /C-/ or $/ \mathrm{CV}-/$ roots, depending on the kind of suffix attached to them.

(26) C- or CV- roots

Infinitive

beétta 'to go'

meétta 'to eat' maaná

geétta 'to say' gaaná

yeétta 'to come' yaaná $\underline{\text { Imperfect }} \quad \underline{\text { Imperative }} \quad \underline{\text { Jussive }}$

bá biité bó bóná

má muité mó móná

gá güté gó góná

yá yüté yó yóná

In a synchronic description, the above verbs should be treated as $C$ - verb roots rather than $\mathrm{CV}$ - verb roots because some morphemes, e.g., the signular imperative and jussive morphemes above, are affixed to the consonant. Further more, where they appear as CV-roots, as in the infinitive, imperfective, and plural imperative forms, the vowel quality varies according to the kind of suffix. Based 
on this latter fact one can also argue that these are CV-verb roots with an underspecified vocalic slot. This leaves open the question of why the vocalic element is not realised in all verb inflections.

C- verb roots have a tone-accent like that of unaccented verb roots, except in their infinitival form. Infinitival, unaccented verbs have the high tone-accent on the final vowel of the suffix and, hence, the word. C- verbs, however, have the tone-accent on the first vowel of the word, which, because of the moraic rule for long vowels, occurs on the second mora of that vowel. In this respect, they pattern with the accented roots, which also have the tone-accent on the first vowel of the word.

Inflection of the verb for negation also results in different tone-accent patterns, which are shown in (27).

(27) Unaccented Roots

\section{a.The Perfective Negative} šammábéyke šammábákká šammíbénná šammábéykú šammíboókko šammíbékkétá šammíbókkóná

$$
\begin{aligned}
& \text { 'I did not buy' } \\
& \text { 'you did not buy' } \\
& \text { 'he did not buy' } \\
& \text { 'she did not buy' } \\
& \text { 'we did not buy' } \\
& \text { 'you (pl.) did buy' } \\
& \text { 'they did not buy' }
\end{aligned}
$$

b. Imperfective and Future Negative

$\begin{array}{ll}\text { šammikke } & \text { 'I do/will not buy' } \\ \text { šammákká } & \text { 'you do/will not buy' } \\ \text { šamménná } & \text { 'he do/will not buy' } \\ \text { šammúkkú } & \text { 'she do/will not buy' } \\ \text { šammókko } & \text { 'we do/will not buy' } \\ \text { šammékkétá } & \text { 'you (pl.) do/will not buy' } \\ \text { šammókkóná } & \text { 'they do/will not buy' }\end{array}$

Accented Roots

c. The Perfective Negative

$\begin{array}{ll}\text { wuúk'k'ábéyke } & \text { 'I did not steal' } \\ \text { wuúk'k'ábákká } & \text { 'you did not steal' } \\ \text { wuúk'k'ibénná } & \text { 'he did not steal' } \\ \text { wuúk'k'ábéykú } & \text { 'she did not steal' } \\ \text { wuúk'k'iboókko } & \text { 'we did not steal' } \\ \text { wuúk'k'ibékétá } & \text { 'you (pl.) did not steal' } \\ \text { wuúk'k'ibókóná } & \text { 'they did not steal' }\end{array}$

d. Imperfective and Future Negative

$\begin{array}{ll}\text { wuúk'k'íkke } & \text { 'I do/will not steal' } \\ \text { wuúk'k'ákká } & \text { 'you do/will not steal' } \\ \text { wuúk'k'énná } & \text { 'he does/will not steal' } \\ \text { wuúk'k'úkkú } & \text { 'she does/will not steal' } \\ \text { wuúk'k'ókko } & \text { 'we do/will not steal' } \\ \text { wuúk'k'ékkétá } & \text { 'you do/will not steal', } \\ \text { wuúk'k'ókkóná } & \text { 'they do/will not steal' }\end{array}$

The negative morpheme has different forms for the different person-number inflections. Thus, the perfective negative inflection in (27a) should be analysed as in (28).

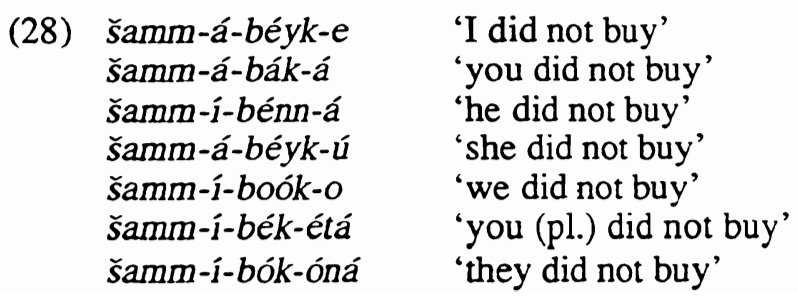


The subject markers are the discontinuous morphemes /á....e/ for first person, (á....a) for second person, and so forth. The negative marker, even though it synchronically appears to be part of the inflected verb and has varying forms for the different persons, must have been a separate word with its own tone-accent, which at a later stage became cliticised to the verb. One piece of evidence for this is the high tone-accent on the negative morpheme in the first person singular and plural inflections. Here, tone-accent remains on the negative marker, while in the other persons it is assigned to the person markers as well. The same holds for the inflection of the imperfective negative, which also has no tone-accent on the discontinuous first person marking morphemes. (This imperfective negative morpheme itself must have undergone vowel reduction, since now only a nontone-accent bearing unit, /-nn-/ for third person masculine and /-kk-/ for all other persons, marks the imperfective negative.)

3.2.3. Verb Derivation. The affixation of passive and causative morphemes does not affect the location of tone-accent. Here, only causative verb derivation for /šamm-/ 'buy' and /wuúk'-/ 'steal' and the derivation of jussive forms from adjectives are discussed.

(29) šam-iss-aási 'I made somebody buy' (compare šamm-aási 'I bought') wuúk'-iss-iisi 'he made somebody steal' (compare wuúk' $k$-iisi 'he stole')

Tone-accent remains on the inflectional morphemes in double causative forms as well, as shown in (30).

(30) šam-is-iss-iísi

buy-CAUS-CAUS-3MS.PST

'He got someone to make someone else buy'

The same can be observed in the Future (31).

(31) taaní šam-iss-aná

taaní wuúk'-is-iss-ana
'I will make somebody buy'

'I will make somebody make someone else steal'

The causative morpheme /-is/ is geminated before inflectional morphemes. The motivation for the gemination of this and related derivational and inflectional forms, as in wozaná 'heart' and wozannaámá 'one with good memory', wuúk ettá 'to steal' and wuúk' Kaasi 'I stole', for example, is an interesting topic for future research.

In the derivation of jussive verb forms from adjectives, the masculine form $/-o /(32 a)$ or the feminine $/ u-/(32 b)$ is suffixed to the adjective, replacing the 
final vowel of the adjective. This suffixation results in a shift in the tone-accent of the base form. 8

\begin{tabular}{|c|c|c|c|c|}
\hline $\begin{array}{l}\text { lo??ó } \\
\text { daró } \\
\text { samó } \\
\text { boot't'ó }\end{array}$ & $\begin{array}{l}\text { 'let it/him be good' } \\
\text { 'let it be plenty' } \\
\text { 'let it be rotten' } \\
\text { 'let it/him be white' }\end{array}$ & $\begin{array}{l}< \\
< \\
< \\
<\end{array}$ & $\begin{array}{l}\text { lóp?o } \\
\text { dáro } \\
\text { sáma } \\
\text { boótta }\end{array}$ & $\begin{array}{l}\text { 'good' } \\
\text { 'plenty' } \\
\text { 'rotten' } \\
\text { 'white' }\end{array}$ \\
\hline $\begin{array}{l}\text { karet't'ú } \\
\text { Pazallú }\end{array}$ & $\begin{array}{l}\text { 'let her be black' } \\
\text { 'let her be lazy' }\end{array}$ & & $\begin{array}{l}\text { karétta } \\
\text { Pazálla }\end{array}$ & lazy' \\
\hline
\end{tabular}

Based on the above description, Wolaitta verb roots can be grouped into two sets: accented and unaccented. In accented verbs, high tone-accent is marked on the first vowel except when the first syllable contains a long vowel. In such cases, it is the second mora of the first vowel that receives tone-accent. For unaccented verbs, it is not possible to identify the location of the high tone-accent on the inflected verb as 'ultimate' or penultimate'. In the inflection of such verbs for perfective and imperfective aspect, for example, the first mora (or the second mora of those suffixes beginning with a long vowel) is marked for tone-accent, irrespective of the relative distance from the right edge, which seems to determine nominal tone-accent marking. Compare, for example, /šamm-ídosona/ 'they bought', and /šamm-ída/ 'we bought' and /šamm-anál 'I, you, etc. will buy'. Thus, in verb inflection, tone-accent pattern depends on 1) whether or not the verb root is accented, and 2) the place of tone-accent on the suffix. This appears to be the case in other Ometo languages as well. Hayward [1990a: 440], states the following about the Zayse tone-accent pattern in verbs: "In the case of verbs, accentual placement varies according to the paradigm concerned, and could therefore be regarded as a part exponent of the category (categories) expressed in that paradigm."

Suffixes, then, are of two types: those that shift the location of tone-accent and those that do not. "Accent integrating" morphemes, to borrow Newman's [1986] terminology, affect the tone-accent pattern of the base form. Examples of this type are shown in the derivation of nominals such as /laggéta/ 'friendship' (from llágge/ 'friend') and in the vocative form, which alter the tone-accent of the base form. The same phenomenon can also be observed in the derivation of jussive forms from adjectival bases. Some suffixes, on the other hand, do not affect the tone-accent of the verb root. When suffixed to accented verb roots, the root retains its tone-accent while the suffix remains unaccented. For example, aspect,

8 Next to the usual 'predicative' and 'inchoative' form, adjectives can be basis for the derivation of abstract nominals and jussive verb forms. When used in non-attribute position, they inflect for person and case. Thus, from /lóPPo/ 'good', /loP?ótetta/ 'goodness', /lóPlotil 'the good ones (nom.)'; /ló??ota/ 'the good ones (acc.)'; /lo??ibenná/ 'it was not good'. Also /lo??o ka?iusi/ 'it is well cooked'. 
person, number, and gender morphemes (which are inseperable in the perfective and imperfective), as well as infinitive and imperative mood suffixes, are not accented when affixed to accented verb roots. However, when the same morphemes are affixed to unaccented verb roots, a tone-accent is marked on the suffixes themselves. We label these morphemes "non accent integrating" morphemes because their affixation to an accented base does not change the location of accent. We also include in this class jussive and negation morphemes, which do not alter the accent of the base form but add to it their own tone-accent, resulting in two or more accented moras in a word.

\section{Phrases}

4.1. Noun Phrases. When nouns occur with modifiers, the position of the toneaccent may be affected. Consider the case of quantified nouns. When numerals up to 'four' are uttered in isolation, tone-accent is marked on the last vowel (33).
(33) Rissó 'one'9
naa?á 'two'
heezzá 'three'
Poyddá 'four'

Numerals for 'five' /Piččáša/ and 'ten' /támma/ both have penultimate toneaccent. Between five and ten, numerals have tone-accent on their ante-penultimate vowel, as in (34).
(34) ?usúppuna 'six'
laáppuna 'seven'
hóspuna 'eight'
Pudúpuna 'nine'

Numerals beyond ten are formed by a combination of /támma/ 'ten', the conjunction marker /-nne/, and the lower numerals, such as /naa?á/ 'two', /heezzá/ 'three', and /Riččášal 'five' (35).
(35) tammanne naa?á
'twelve'
tammanne Piččáša
'fifteen'
hastammanne heezzá
'thirty three'

\footnotetext{
9 In modifying positions, the last vowel of the numeral is changed to /i/ or / $/ /$ as in: /RissI na?i/ 'one child'; /naaßí naali/ 'two children'; / heezzú naati/ 'three children'. Those higher numerals that have /-puna/ are different. Thus, we have /?usúppun naatil 'six children', /laáppun naati/ 'seven children'.
} 
In such combinations, it is the lower numerals that are marked for tone-accent. The tone-accent assignment of these numerals is different from what can be observed in compounds and phrases. Even though numerals above ten consist of three morphemes, the location of the high tone-accent makes them look like one single form.

In quantified noun phrases, illustrated in (36), the head noun loses its toneaccent. If the preceding modifier carries a penultimate high tone-accent, the latter is extended onto the final vowel of the same word.

$\begin{array}{lll}\text { (36) naa?ú hareti } & \text { 'two donkeys' } & \text { (haretí 'donkeys') } \\ \text { naa?ú kušeti } & \text { 'two hands' } & \text { (kúšeti 'hands') } \\ \text { Piččásúu kušeti } & \text { 'five hands' } & \text { (Piččáša 'five') } \\ \text { támmú naati } & \text { 'ten children' } & \text { (támma 'ten', naatí 'children') } \\ \text { Pubbá kušeti } & \text { 'all hands', } & \text { (Pubbá 'all', kúšeti 'hands') } \\ \text { guúttá suk'k unta 'few ashes' } & \text { (guútta 'few, little', súk'k'unta 'ashes') }\end{array}$

The same process is observed with adjectives (37). The adjective as a modifier retains its inherent high tone-accent but high tone extension or spreading occurs in those adjectives that have penultimate high tone-accent in their citation form.

(37)

karéttá miizziya 'the black cow'

k’ántá miširiya

lóp?ó huup'e

woggá haree 'the short woman'

'good hair'

'the big donkey' (karétta, miízziya)

(k'ánta, miširiyá)

(lóP?o, huúp'e)

(woggá, harée)

Similarly, in the relative clause, it is the clause-final verb of the relative clause, not the head noun, that is marked for tone-accent, as in (38).

(38) a. Pašo šamm-ída na?- ay meat buy-REL child-NOM (MASC.)

'The boy who bought meat'

b. mǚša demm-ída na?-iya money find-REL child-NOM (FEM.)

'The girl who found money'

It was shown in section 3.1 .2 (examples in 15) that affixation of nominalizing morphemes such as /ámá/ and /-ánčá/ to simple nominals and adjectives allows the derived word to have more than one high tone-accent. When these derived nominals are used as modifiers of other nominals, they keep this double toneaccent pattern (39). 

(39) wolk’ámá asa
'strong person'
doonámá asa
'talkative person'
goššánčá keetta
'a farmer's house'
hargánčá t’aliya
'a patient's medicine'

4.2. Adjectival Phrases. Adjectival phrases have the same tone-accent pattern as noun phrases, since here, too, the specifier, not the head, is marked for toneaccent.

(40) dáró k'anta 'very short' (but, dáro 'a lot', k'ánta 'short') dáró loß?o 'very good' (but, lóP̧o 'good')

If these phrases modify other nouns, then the adjectives attract high tone-accent from the head noun (41).

(41) dáró k’ántá Pasa 'a very short person' dáró lóP’ó Pasa 'a very good person'

As in noun phrases, numerals attract tone-accent in adjectival phrases and, as heads, adjectives lose their tone-accent.

(42) naa?ú k'antati 'the two short ones' (naa?á 'two', k'ántati 'short ones') Pissí woggay 'one big one' (Pissó 'one', woggá 'big')

When these adjectival phrases modify a noun, then the adjective is reassigned high tone-accent:
(43) naa?ú k'ántá Pasati 'two short persons'
Rissí woggá kanay 'one big dog'

In expanded noun phrases, each modifier, except for the singular demonstratives, carries high tone-accent.

(44) a. hageetí naa?ú Padussá naati these two tall boys

b. hegeetí heezzú kántá hareti those three short donkeys

c. ha lo?Pó Padussá huup'e this nice long hair' 
4.3. Postpositional Phrases. There are a few independent postpositions in Wolaitta. All of these have high tone-accent on the final vowel (45).
(45) bollá 'on' as in /keettáa bolla/ 'on the house' garsá 'in' /inside/
guyyé 'behind'
miyyé 'beside'

There are also bound postpositional morphemes in Wolaitta, which, when suffixed to a definite noun with a long final vowel, result in high tone-accent on both moras. Compare the following definite and indefinite postpositional phrases: miččééppe 'from the sister' and miččíppe 'from a sister'; kúšééppe 'from the hand (diminutive)' and kúšéppe 'from a hand'; keettááppe 'from the house' and keettáppe 'from a house'. Further examples on the tone-accent pattern of postpositional phrases formed by a postpositional suffix and (definite) nouns with different location of high tone-accent in their citation form are given below.
(46) a. šaáfa 'river'
šaáfáá-ppe 'from the river'
b. miččó 'sister'
miččéé-ppe
šaáfáá-kko 'to the river'
miččéé-kko
šaáfáá-ra 'with the river'
miččéé-ra
šaáfáá-yyo 'for the river'
miččéé-yyo

c. kưše 'hand'
kúšiyáá-ppe
kúsiyaáá-kko
kúšiyáá-ra
kúšiyáá-yyo

(47) a. Ti šaáfááppe yiis

b. Ti saáfááko biis

c. Ri miiššáa ba miččééppe ekkis 10

d. Ti ba miččééko biis

e. İ ba miččééra biis

f. Ti miišsáa ba miččééyo Pimiis
'He came from the river'

'He went to the river'

'He took money from his sister'

'He went to his sister'

'He went with his sister'

'He gave the money to his sister'

Postpositional phrases lose their tone-accent when modified by other categories.
(48)
ló?ó na?aape
'from the nice boy'
guúttá kušeeppe
'from the little hand'

In all major lexical categories discussed so far, we have not encountered long vowels with high tone-accent on both moras. In nouns, adjectives, and verbs with accented long vowels, the right most mora receives high tone-accent, e.g. /miizza/ 'cow', /keéha/ 'kind', and /laáletta/ 'to scatter'. The only exceptions to this rising tone-accent in nouns are final accented inflected nouns as in /zarée/ 'the lizard (nominative)' and /harée/ 'the donkey (nominative)' from /zarél 'lizard' and

${ }^{10}$ The morpheme /ba/ in the last four sentences refers to third person possessor. 
/harél 'donkey', respectively (see 3.1.1). The case of accented long vowels in postpositions shown above is parallel to the occurrence of extra high tone-accent on the final vowel of numeral or adjectival modifiers in noun phrases (see sections 4.1 and 4.2 above.).

\section{Compounding}

In terms of tone-accent patterns, nominal compounds behave like phrases in that the nouns involved, each with their inherent high tone-accent in isolation, take only one tone-accent when combined. This high tone-accent is always placed on the first component of the compound noun, as is the case with numeral and adjectival modifiers in noun phrases.
a. hayttá
'leaf'
tukké
'coffee'
hayttá tukke 'spicy coffee made from coffee leaves'
b. haattá 'water'
hargé 'illness'
haattá harge 'algae'
c. gillá 'small'
kúse 'hand'
gil’á kuše 'little finger / the fifth finger'
d. goóšsa
giyá
goóšsá giya
'crazy'
'market'
$\begin{array}{ll}\text { e. yeehó } & \text { 'mourning' } \\ \text { keettá } & \text { 'house' } \\ \text { yeehó keetta } & \text { 'mouming house' }\end{array}$

\section{Unaccented categories}

It was shown in the previous sections that, in phrases, it is the specifiers which always take the tone-accent. But this generalization does not extend to demonstratives and possessive pronouns.

6.1. Demonstratives. Contrary to the case with numerals, adjectives, and relative clauses, singular demonstratives do not carry high tone-accent. Also, the modified noun retains its inherent tone-accent. 
(50) ha haretí 'these donkeys' (ha 'this' hareti 'donkeys')

ha kúšeti 'these hands' (ha 'this' kúšeti 'hands')

he miizzati 'those cows' (he 'that' miizzati 'cows')

The demonstratives /ha/ 'this' and /he/ 'that' have longer variants /hagé/ and /hegé/, respectively, which carry their own tone-accent when uttered in isolation. But even these full forms do not get high tone-accent as other specifiers of a noun would.

(51) hage harée 'this donkey (nom.)',
hege haree 'that donkey (nom.)'
hega hariya 'that donkey (acc.)'

But the plural morpheme on demonstrative pronouns does carry a high toneaccent. Note, however, that the noun retains its inherent tone-accent:

(52) hegeetí haretí 'those donkeys (nom.)' hegeetá haretá 'those donkeys (acc.)'

6.2. Pronominal Possessives. The second set of specifiers that do not carry tone-accent are possessive pronominals.

$\begin{array}{llll}\text { (53) a. ta haré } & \text { 'my donkey' } & \text { b. ta kúše } & \text { 'my hand' } \\ \text { ne haré } & \text { 'your donkey' } & \text { ne kúšse } & \text { 'your hand' } \\ \text { Pa haré } & \text { 'his donkey', } & \text { Pa kúše } & \text { 'his hand' } \\ \text { Pi haré } & \text { 'her donkey' } & \text { Pi kúse } & \text { 'her hand' } \\ \text { nu haré } & \text { 'our donkey' } & \text { nu kúse } & \text { 'our hand' } \\ \text { Pinte haré } & \text { 'your (pl) donkey' } & \text { Pinte kúse } & \text { 'your (pl) hand' } \\ \text { Peta haré } & \text { 'their donkey' } & \text { Peta kúše } & \text { 'their hand' }\end{array}$

The unaccented demonstratives /ha/ and /he/, which are short forms of /hagé/ 'this' and /hegé/ 'that', as well as the first person singular/plural and second and third person singular possessive pronominals, are the shortest possible non-verbal forms in Wolaitta, consisting of just CV. Thus, parallel to languages like Somali (Hyman [1981:182]), one could argue that these forms do not satisfy the structural description of independent lexical categories in Wolaitta and, therefore, cannot be assigned tone-accent. However, shorter variants of subject pronouns shown in section 2.2, which are segmentally identical to possessive pronouns do receive high tone-accent. Each of the forms in (53) above would give a different meaning if the pronoun forms were accented, as illustrated in (54a and b) below which, without the accent marker on / $\mathrm{K} /$, translate as 'her donkey' and 'her hand', respectively. 
(54) a. Ti haré

he donkey

'He is a donkey' b. ใ̊ kúše

he hand

?'He is a hand'

Subject pronouns carry their own high tone-accent, as in (55) and (56).

(55)
a. tá Pašó m-aaysi
I meat eat-1S IMPF
'I eat meat'

(56) a. né Pašó m-aasa

you meat eat-2S IMPF

'You eat meat' $\begin{array}{ll}\text { b. taaní Pašó } & \text { m-aaysi } \\ \text { I meat eat-1S IMPF } \\ \text { 'I eat meat' }\end{array}$

b. neení Pašó m-aasa

you meat eat-2S IMPF

'You eat meat'

\section{Discussion and conclusion}

The description of the Wolaitta tone-accent system in this paper was based on the claim that in tone-accent languages there is a restricted occurrence of high toneaccent. However, it was shown that this is the case only with simple lexical categories. There is deletion and shift of high tone-accent in various categories, a phenomenon said to be typical of accent languages. Furthermore, through derivation, words may be marked for more than one high tone-accent, a property which is common in tone languages. This places Wolaitta somewhere between 'tone' languages and "stress" or "accent" languages as defined in various studies. For example, Childs [1989:141], in his discussion on the relationship between tone and accent with regard to African prominence systems, states that

...the basic distinction that is usually made between the two is that tone is paradigmatic and accent is syntagmatic. In a paradigmatic system, any number of units can have equal prominence, e.g., a series of high tones is possible. ... In a syntagmatic system, on the other hand, the location of the accented unit is crucial; only one unit in a phonological phrase is allowed to have prominence, e.g., a sequence of two accented syllables in a phonological phrase is ungrammatical.

Tone accent marking in phrases can be predicted from the tone-accent of the modifier(s). That is, if a single modifier is present and if this modifier has final tone-accent, the phrase will have only one high tone-accent. If the modifier has penultimate high tone-accent, this accent spreads to the final mora of the modifier. In all cases, it is the modifier that bears high tone-accent, not the head of the phrase. This could indicate the prosodic function of tone-accent, that high tone-accent in a phrase marks the boundary between modifier and head. It might also explain tone spread to the last vowel of modifier words which have high tone-accent in the penultimate position (57). 


$\begin{array}{lllll}\text { (57) lópPo } & \text { 'good' } & > & \text { lóPPó huup'e } & \text { 'good hair' } \\ \text { dáro } & \text { 'a lot' } & > & \text { dáró lo?Po } & \text { 'very good' } \\ \text { karétta } & \text { 'black' } & > & \text { karéttá miizziya } & \text { 'the black cow' } \\ \text { guútta } & \text { 'small' } & > & \text { guúttá suk'k unta } & \text { 'little ashes' }\end{array}$

When complex, derived words with more than one high tone-accent are used in a phrase, they keep their tone-accent.

The data presented here also show that the domain of tone-accent marking in Wolaitta is not the syllable. Evidence for this is derived from the fact that in uninflected words with long vowels, it is the second mora of the long vowel that is marked with high tone-accent, whereas in inflected words with a long vowel in final positions, it is the first member of the long vowel that receives high toneaccent.

The pattern of complex tone-accent marking in negative verbs and in derivational processes suggests that morphology is highly relevant for our understanding of the function of pitch in Ometo as well as of the historical development of alternative (i.e., classical tonal) systems in other Omotic languages. According to Wedekind [1985], for example, the historical development of the Bench language to a system having five level tones and one gliding tone can be partially explained on morphological grounds.

\section{REFERENCES}

Adams, Bruce. 1983. "A Tagmemic Analysis of the Wolaitta Language." Ph.D. Thesis, University of London.

Allan, Edward J. 1976. "Dizi." In M.L. Bender, J. D. Bowen, R. L. Cooper, C. A. Ferguson (eds.), Language in Ethiopia, pp. 377-392. London: Oxford University Press.

Banti, Giorgio.1988. "Two Cushitic Systems: Somali and Oromo nouns." In Harry Van der Hulst and Norval Smith (eds.), Autosegmental Studies on Pitch Accent, pp. 11-50. Dordrecht: Foris Publications.

Breeze, Mary. 1988. "Phonological features of Gimira and Dizi." In Marianne Bechhaus-Gerst and Frits Serzisko (eds.), Cushitic-Omotic: Papers from the International Symposium on Cushitic and Omotic Languages, Cologne, January 6-9, 1986, pp. 475-87. Hamburg: Helmut Buske Verlag. 
Childs, G.Tucker. 1989. "The extra-high tone of Kisi: Just another tone or a new system of prominence?" In Paul Newman and Robert D. Botne, (eds.), Current Approaches to African Linguistics (vol. 5), pp. 141-50. Dordrecht: Foris Publications.

Fleming, Harold. 1976. "Cushitic and Omotic." In M. L. Bender, J. D. Bowen, R. L. Cooper, C. A. Ferguson (eds.), Language in Ethiopia, pp. 34-53. London: Oxford University Press.

Ford, Carolyn. 1990. "Notes on Koorete phonology." In R.J. Hayward (ed.), Omotic Language Studies, pp. 413-24. London: SOAS.

Hayward, Richard J. 1987. "Terminal vowels in Ometo nominals." In Herman Jungraithmayr and Walter W. Müller (eds.), Proceedings of the Fourth International Hamito-Semitic Congress, Marburg, 20-22 September 1983, pp. 215-231. (Current Issues in Linguistic Theory, 44.) Amsterdam and Philadelphia: John Benjamins.

Hayward, Richard J. 1990a. "Notes on the Zayse language." In R.J. Hayward (ed.), Omotic Language Studies, pp. 210-355. London: SOAS.

Hayward, Richard J. 1990b. "Notes on the Aari language." In R.J.Hayward (ed.), Omotic Language Studies, pp. 425-93. London: SOAS.

Hayward, Richard J. 1994. "A Preliminary Analysis of the Behaviour of Pitch in Gamo." In Bahru Zewde, Richard Prankhurst, and Taddese Beyene (eds.), Proceedings of the Eleventh International Conference of Ethiopian Studies. Vol. I, pp. 481-94. Addis Ababa: Addis Ababa University Press.

Hyman, Larry. 1981. "Tonal accent in Somali." Studies in African Linguistics 12 (2): 169-203.

McCawley, James. 1978. "What is a tone language?" In V.A. Fromkin (ed.), Tone: A Linguistic Survey, pp. 113-131. New York and London: Academic Press.

Newman, Paul. 1986. "Tone and affixation in Hausa." Studies in African Linguistics. 17 (3): 249-69.

OPHCC. 1991. The 1984 Population and Housing Census of Ethiopia: Analytical Report at the National Level. Addis Ababa: Office of the Population and Housing Census Commission, Central Statistical Authority. 
Van der Hulst, Harry and Norval Smith (eds.). 1988. "The variety of pitch accent systems: Introduction." Autosegmental Studies on Pitch Accent. pp. ix-xxiv. Dordrecht: Foris Publicatons.

Van der Hulst, Harry. In press. "Word accent." In Harry Van der Hulst (ed.), Word Prosodic Systems in the Languages of Europe. Berlin and New York: Mouton de Gruyter.

Wedekind, Klaus. 1983. "A six-tone language in Ethiopia: tonal analysis of Benc ${ }^{4}$ non $^{4}$ (Gimira)." Journal of Ethiopian Studies 16: 121-56.

Wedekind, Klaus. 1985. "Why Bench' (Ethiopia) has five level tones today." In Ursula Pieper and Gerhard Stickel (eds.), Studia Linguistica Diachronica et Synchronica, pp. 881-901. Berlin: Mouton de Gruyter.

Wedekind, Klaus. 1990. "Gimo-Jan or Ben-yem-om: Bench Yemsa phonemes, tones and words." In R.J. Hayward (ed.), Omotic Language Studies, pp. 68184. London: SOAS.

Withgott, M. and P. Halvorsen. 1988. "Phonetic and phonological considerations bearing on representation of East Norwegian accent." In Harry Van der Hulst and Norval Smith (eds.), Autosegmental Studies on Pitch Accent, pp. 279-94. Dordrecht: Foris Publications.

Yitbarek Ijigu. 1983. "The phonology of Wolaitta." M.A. Thesis, Addis Ababa University.

Department of African Linguistics

Leiden University

P.O. Box 9515

2300 RA Leiden

Netherlands
[Received January 30, 1996; revision received October 3, 1996; accepted October 16, 1996] 